\title{
The Impact of Credit Risk Management and Macroeconomic Variables on Bank Performance in Nigeria
}

\author{
ISIBOR AREGHAN AKHANOLU ${ }^{1}$, OMANKHANLEN ALEXANDER EHIMARE ${ }^{2}$, CHIMA $^{2}$ \\ MENYELIM MATHIAS ${ }^{3}$, KOMOLAFE TITILOPE DEBORAH $^{4}$, OKEREKE KARACHI \\ YVONNE $^{5}$
}

\author{
1, 2, 3, 4, \& 5 Department of Banking and Finance, Covenant University, Ogun State, NIGERIA
}

\begin{abstract}
The aim of this paper is to identify the main impact that credit management and macroeconomic variables have on bank performance in Nigeria. The reason for this is the numerous high level of deposit money

banks' bad debt based on available data. The bad debt tended to have a negative effect on performance. To this end, the researchers conducted a study using macroeconomic data, and other indicators of credit management and bank performance from 2009-2017 using 12 deposit money banks in Nigeria. The ordinary least square (OLS) method was utilized to determine the factors that explains the subject matter. The result showed the presence of a positive connection between the capital adequacy proportion and the sum national income on the Return on Asset. Therefore, Depositing Money Banks with a greater proportion of capital sufficiency can all the more likely develop more advances and retain credit misfortunes whenever it occurs and thus document better financial productivity as for the assets.
\end{abstract}

Key-Words: - Macroeconomic, Credit management, Bank performance, Productivity, Credit Risk Management, Ordinary least square

Received: May 18, 2020. Revised: November 30, 2020. Accepted: December 15, 2020. Published: December $27,2020$.

\section{Introduction}

The delight of every bank in the world is to run a successful banking business that would eventually result to profit. Banks therefore in order to maintain profitability must be able to provide adequate possibility to provide the needs of every customer, through loans and advances, deposits, savings and lots more. The banking sector is said to have an adequate contribution to the development of an economy in any nation and this is where the failure and success of every bank lies between economic sector and the economy at large is been affected,

Having seen all the vital or significant contribution that the banking industry has to the market as well as the growth of the country's economy, the federal government decides to create regulatory authorities to better regulate the industry's activities. So its donations to the Nigerian industry can be favorably thought. Regulatory bodies, however, compelled Nigeria's financial industry several years ago to perform reforms arising either from the Central Bank of Nigeria's need for organizations to raise their cash reserves (share) to at least ten billion naira (N10b) for domestic banking, twenty-five billion naira (N25b) for regional banking and fifty billion naira (N50b) for global finance. Nigerian banks have still seen many instances of collapse given the initiatives and plan. This could be due to poor credit management. Banks are one of a country's major economy drivers, particularly in Nigeria, and any small-performing bank impacts the country in general [25]. Several works like [3] and [26] has been undertaken on how bankers' intermediate position affects bank lending, and also Some relevant studies can be found in [33] and [34] and that is why credit risk is viewed as one of the major obstacles affecting bank efficiency.

Furthermore, Profitable financial intermediation has the ability to transfer their investments to products that increase in the amount of funds handled in the national economy [22]. According to [18], the primary drivers of financial variations are: increase in manufacturing, growth in demand, development in asset, employment and labor wages, inflation prices, shifts in relative equity prices, tax policy, loan rates, rise in loans and development in total wealth [14]. However, it included that, when 
financial institutions grant accessible loans, future projections of macro situations should be regarded and obtained when granting loans to clients, in relation to the loan status of credit. Various studies have been researched on how credit management is affected in banks which hereby result to either positive or negative impact on banks performance or profitability. [9] researched on the impact of credit management on bank performance in Nigeria, also, [32] imputed on the credit management and bank performance of listed banks in Nigeria, [8] also looked at the credit risk management and profitability of Nigerian deposit-money banks. It is seen that credit is one of the major risks that affects banks and its environment. However various other studies were analysed and research by both foreign and local researchers [17] researched on the impact of social and economic factors in the credit risk management of SMEs, also [12] focused on macroeconomy and bank profitability in Nigeria. Where [13] looked into the credit risk and economic growth in Nigeria saying that lending and borrowing are the life wire of economic growth. However, adequate researched has not been channelled into the interaction between credit management and macroeconomic factors on bank performance as its related to credit management where financial institutions are regarded as a contribution to the growth of an economy, it is essential that macroeconomic factors are regarded when measuring the profitability of banks and how credit management is affected by it. However, this research aims to assess the interactive impact of credit management and macroeconomic factors on bank performance by comparing independent and dependent variables of the macroeconomic, credit management and bank performance variable using the ordinary least squares regression technique.

\section{Empirical Review}

In recent times, credit management and bank performance has appealed to a number of researchers in advanced and developing economies, of which [19] examined the empirical effect of credit risk on the performance of commercial banks in Nigeria over an 11-year span (2000 - 2010). Five Banks were selected for 11 years on a crosssectional level. The result shows that the effect of credit risk on Bank Performance measured by the Bank's Return on Asset is longitudinal symmetric.

[16] investigated the effect of banks ' credit risk and efficiency over a 15-year period (1997-2011) with five banks selected from the existing twenty Nigerian banks implementing sampling technique.
In the survey, information was acquired from the company's financial statements and reports statements the result suggests that the number of non-performing loan to loan and advances (and performance of the banks are positively related. also, there is a strong relationship between loan percentage and total deposit advances and bank performance advances. [10] examined the effect of how credit risk management affect the profitability and survival of bank profitability in Iran, for this aim, the model used is the panel data method of the financial statement of these banks from 2005-2016. The result showed that there was a significant relationship between credit risk management and profitability of bank survival. [12] also identified the macroeconomic factors that explain credit risk management In the Algerian banking system. The study used macroeconomic data from 1980 to 2014 and also used the Ordinary Least Squares (OLS) method to determine the factors that explain the credit risk in the Algerian banking system. The results showed that credit risk in Algerian banks can be relatable at macroeconomic level mainly by the financial development, GDP, money supply and political stability of the country.

\subsection{Information Asymmetry Theory}

This study focuses on the concept of information asymmetry, since the theory is very applicable to this research. The theory of asymmetric information clarifies the general information that creditors and business owners need to know about risks and goes back connected with capital projects in which the resources are allocated. Recall that assumed information asymmetry presents the banking institutions with two issues: moral hazard (testing philanthropic conduct) and adverse selection (making mistakes in borrowing decisions). This ensures that the "5cs" (character, capacity capital collateral and conditions) A full assessment must be carried out before loans can be afforded. Because banks do not openly have the necessary data for testing loan modifications and monitoring lenders. Big banks face a condition of information asymmetry when testing lending requests.

\subsection{Commercial Loan Theory}

The theory explains that banks should only lend at short term so as to reduce risk increase profitability. It explains that short-term borrowing is less risky for banks and also for small-scale businesses to thrive on. Traders can easily use such loan for working capital and 
other business needs and pay back with ease, thus reducing credit risk.

\section{Data Collection Method/Techniques of Data Analysis}

To perform empirical analysis, the secondary data for this analysis was harvested through the World Bank index (WDI), and the annual reports of 12 (out of 15) sampled listed banks in the Stock Exchange of Nigeria within 2009 to 2017, extracting a total of 108 observations. The 12 deposit money banks are sampled for the research with the use of purposive sampling technique based on Quality requirements for reliable data set over time and also incorporating the systematically important banks of Nigeria.

\subsection{Measures of Variables}

\subsubsection{Bank Performance}

This study measured bank performance using both enterprise value, accounting based measures and net interest margin which accounts for banks profitability. Enterprise value reflects the satisfaction of returns received by stakeholders such as employees, management, shareholders, creditors, public and government under value focused management [21]. The Return on Equity (ROE) is the proportion of net income to total equity which quantifies the return on capital of shareholders. It metrics how well the management uses the money invested by the shareholder to produce wealth [10]. Accounting-based performance will be measured using the Return on Asset, which are the periodic earnings relative to the total asset used to generate operating cash flow. The net interest margin alternatively called Interest rate spreads are defined as a proportion of the differential between interest revenue and interest cost for individual banks to total assets [31].

\subsubsection{Credit Risk Management}

This literature will evaluate administration of credit risk using indicators relevant to management in credit risk, significant to previous academic works and based on their theoretical relevance. The capital adequacy ratio as a metric is measured as the proportion of the capital quantity to the hazard-weighted sum of the bank's reserves, is a calculation of the assets quantity of the bank Based on a proportion of its default exposure biased against risk [27]. This paper noticed a strong positive relationship of literature amongst the capital adequacy ratio and the banking institution output [6]; [1]; [24]; [19]; and [11].

Between numerous indices of default risk and monetary strength, the Proportion for unperforming loans (NPL) is important as an improvement in NPLR is seen as a weakness of bank default regulation, a decline in bank revenues and a foremost cause for the credit emergency [29]. [6], [18], [21], [11], and [23] noticed an opposite effect of un-performing advances on bank productivity. [6] and [7] examined a correlative effect. The percentage of un-performing advances is represented as impaired loans divided by total loans.

Liquidity ratio that is also represented as the loan/deposit ratio was empirically tested with conflicting outcomes. [1] noticed Liquidity Ratio had a strong positive effect on bank output although [4] and [24] observed that the liquidity level have a detrimental effect on the bank financial performance.

\subsubsection{Macroeconomic Variables}

The analysis would aim for a set of macroeconomic variables to reflect the overall economic circumstances. Thus we include Gross Domestic Product (GDP gr), Gross National Income (GNI) and Inflation (INFL) in our regressions as agents of macroeconomic stability and growth.

A strand of literature suggests that gross domestic product tends to reflect a major inverse effect on the un-performing advances as they support macroeconomic stability that enables economic agents to recover their liabilities [28]; [30]. The study includes the cyclical portion of gross domestic product to discern between the expansionary effect and the effects of recessions on non-performing loans. The inflationary rate represents a persistent rise in commodity prices due to the large concentration of currency in the economy, 
which was proxy for the growing proportion of price index (CPI). [3] found that while inflation rate positively influences un-performing advances, the influence tends to be insubstantially. The Gross National Income will also be employed in this research which is composed of gross domestic product plus international resident income component, minus domestic income earned by non-residents.

\subsubsection{Control Variables}

The research set controls for firm features such as bank magnitude, determined using the logged total asset book value computed in its domestic value, [20] was incorporated as a control variable in this analysis for evaluation of the economic performance of the bank. Bank scope allows for cost reduction in financial product delivery in the banking sector [10]. [11] observed a progressive connection between bank scale and bank accomplishment. On the other side, [1] noticed a significantly inverse influence of bank scale on the management of default risk efficacy of Saudi bank.

Second, cash reserve ratio is characterized as a proportion of consumer lodgment sum kept with the apex financial authority. This is the central bank's financial policy instrument for controlling the economy's monetary circulation [2], and it also influences bank profitability [11]. [11] observed that the cash reserve level has a counter effect on productivity of the banks. It can be represented as need of reserves with the apex authority divided by sum of customer lodgment.

\subsubsection{Statistical Analysis and Model Specification}

To test formulated hypotheses, the research diagnosed the interactive association between default risk administration and macroeconomic variable on bank financial accomplishment, employing an adopted and modified model of [32] to analyze the time series data. It also used Ordinary Least Square (OLS) regressions to evaluate the influence of the explanatory variables on endogenous variable. The statistical analysis of the calculations of the parameters is carried out using their Adjusted $\mathrm{R}^{2}$, Fcal, Standard Error, T-cal and at 5\% significance level. The regression models which were adopted and modified from the studies of [32] are stated as follows:

$\operatorname{Perf}_{i t}=\beta_{0}+\beta_{1} \mathrm{CRM}_{\mathrm{it}}+\beta_{2} \mathrm{Macro}_{\mathrm{it}}+\beta_{3} \mathrm{CRR}_{\mathrm{it}}+$ ${ }_{4}$ Lnasset $_{\text {it }}+\mu_{\mathrm{t}}$

Where:

$t=$ the annual year time period for firm $i$

Perf = Financial performance proxied by Return on Asset, Net Interest Margin and Return on Equity.

$\mathrm{CRM}=$ credit risk management proxied by Non-Performing Loan, Capital Adequacy Ratio and Liquidity ratio

Macro $=$ macro-economic variables proxied by Gross Domestic Product Growth Rate, Inflationary Rate and Gross National Income.

Lnasset $=$ the natural logarithm total assets of the firm

$\mathrm{CRR}=$ cash reserve requirement

$\mu_{\mathrm{t}}=$ white error noise 


\section{Result}

Table 1: Descriptive Statistics of Variables

\begin{tabular}{|c|c|c|c|c|c|}
\hline variables & Obs & Mean & S.D. & Min & Max \\
\hline Non-Performing & & .0827964 & .10440 & .008 & .69 \\
\hline \multirow[t]{2}{*}{ Loan (NPL) } & 108 & & 54 & 723 & \\
\hline & & & & 8 & \\
\hline Capital & & .191915 & .11723 & - & .44 \\
\hline Adequacy Ratio & 107 & & 72 & .636 & \\
\hline (CAR) & & & & 2 & \\
\hline Loan to Deposit & & .6323901 & .18367 & .014 & 1.003 \\
\hline \multirow[t]{2}{*}{ Ratio } & 108 & & 86 & 664 & 539 \\
\hline & & & & 4 & \\
\hline \multirow{2}{*}{\multicolumn{6}{|c|}{$\begin{array}{l}\text { Macroeconomic } \\
\text { variables }\end{array}$}} \\
\hline & & & & & \\
\hline Gross Domestic & & .0416667 & .02881 & - & .078 \\
\hline $\begin{array}{l}\text { Product growth } \\
\text { rate (GDP gr) }\end{array}$ & 108 & & 59 & .016 & \\
\hline Inflationary & & .3732222 & .33994 & .108 & .9 \\
\hline Rate (IR) & 108 & & 57 & & \\
\hline Gross National & & 4.737222 & 3.1623 & - & 8.1 \\
\hline \multirow[t]{2}{*}{ Income (GNI) } & 108 & & 39 & 1.11 & \\
\hline & & & & 9 & \\
\hline \multicolumn{6}{|l|}{$\begin{array}{l}\text { Dependent } \\
\text { variables }\end{array}$} \\
\hline Return On & 104 & .4319369 & 1.9157 & -5.7 & 13.9 \\
\hline Equity (ROE) & & & 36 & & \\
\hline Return On Asset & & .0125439 & .03974 & - & .0605 \\
\hline (ROA) & 108 & & 32 & .241 & 655 \\
\hline & & & & 048 & \\
\hline
\end{tabular}

1

$\begin{array}{llllll}\text { Net Interest } & 108 & 7.928176 & .19080 & 7.64 & 8.213 \\ \text { Margin (NIM) } & & & 57 & 509 & 389 \\ & & & & 2 & \end{array}$

Source: Researcher's Computation using eviews 9 (2019)

This section details the findings from Table 1-5 and discussions. Table 1 contains the explanation of variables and the expressive statistics of variables. From the Table, The accounting-based performance has a extreme value of 0.061 and least value of 0.241 . The Return on Equity is 1.9157 on the average. Also the net interest spread has an extreme estimation of 8.213 and 7.645 as its minimum value. For the independent variable, non-performing loan has a maximum of 0.69 and minimum of 0.009 . The capital adequacy ratio has a mean of $19.19 \%$ with standard deviation of $11.7 \%$. The proportion of credit to deposit has a base value of 0.015 and extreme value 1.00. as for the macroeconomic variables; gross domestic product (GDP) has a lowest value of -0.016 and a maximum value of 0.078. Inflationary rate has a minimum value of 0.108 and a extreme value of 0.9 and the gross national income (GNI) has a least value of -1.119 and 8.1 as an extreme estimate.

Table 2 presents the correlation coefficients between variables. The table presents a low correlation within the variables. Hence, there exists no multicollinearity statistical problem in the models. 
Table 2: Correlation Coefficients of Variables

\begin{tabular}{|c|c|c|c|c|c|c|c|c|c|c|c|}
\hline & ROA & ROE & NIM & NPL & LDR & CAR & GNI & IR & GDP & $\begin{array}{c}\text { LOG } \\
\text { ASS } \\
\text { ET }\end{array}$ & $\begin{array}{c}\mathbf{C R} \\
\mathbf{R}\end{array}$ \\
\hline ROA & 1 & & & & & & & & & & \\
\hline ROE & 0.0188 & 1 & & & & & & & & & \\
\hline NIM & 0.253 & -0.1295 & 1 & & & & & & & & \\
\hline NPL & -0.6770 & -0.2803 & 0.3215 & 1 & & & & & & & \\
\hline LDR & 0.2566 & -0.245 & 0.2672 & $\begin{array}{c}- \\
0.2755\end{array}$ & 1 & & & & & & \\
\hline CAR & 0.6588 & -0.0986 & $\begin{array}{c}- \\
0.0617\end{array}$ & $\begin{array}{c}- \\
0.5422\end{array}$ & 0.1650 & 1 & & & & & \\
\hline GNI & -0.1147 & 0.0885 & $\begin{array}{c}- \\
0.7804\end{array}$ & 0.1066 & -0.3076 & 0.0265 & 1 & & & & \\
\hline IR & 0.1633 & -0.0443 & 0.1955 & $\begin{array}{c}- \\
0.2915\end{array}$ & 0.0658 & -0.0562 & 0.2631 & 1 & & & \\
\hline GDP & -0.1358 & 0.113 & $\begin{array}{c}- \\
0.8376\end{array}$ & 0.1851 & -0.3143 & 0.0421 & 0.9758 & $\begin{array}{l}0.102 \\
5\end{array}$ & 1 & & \\
\hline $\begin{array}{l}\text { LOG } \\
\text { ASSE } \\
\mathbf{T}\end{array}$ & 0.333 & -0.0976 & 0.4315 & $\begin{array}{c}- \\
0.3562\end{array}$ & 0.1984 & 0.2038 & $\begin{array}{c}- \\
0.3068\end{array}$ & $\begin{array}{c}0.175 \\
3\end{array}$ & $\begin{array}{c}- \\
0.346\end{array}$ & 1 & \\
\hline CRR & 0.2621 & -0.1187 & 0.9369 & $\begin{array}{c}- \\
0.3720\end{array}$ & 0.2971 & -0.0617 & $\begin{array}{c}- \\
0.6470\end{array}$ & $\begin{array}{c}0.484 \\
7\end{array}$ & $\begin{array}{c}- \\
0.756 \\
1\end{array}$ & $\begin{array}{c}0.440 \\
1\end{array}$ & 1 \\
\hline
\end{tabular}

Source: Researcher's Computation using eviews 9 (2019)

Table 3- 5 reports the emphasis of this study which is based on the Ordinary Least Square (OLS) regression to capture the linear interactive effect in this financial performance study.

Table 3 shows the influence of the interaction between progression rate of GDP and nonperforming loan on Return on Equity by presenting the OLS outcome at a P-value of 0.0179 with $\mathrm{R}^{2}$ equaling 0.1283 . This means that including control variables, macroeconomic variables and credit risk management explain $12.83 \%$ of the Return on Equity. From the table, the interaction between GDP progression rate and non-performing advance is positively significant on Return on Equity. The positive coefficient could signal a favorable effect on Return on Asset. However, un-performing advance has an insignificant inverse influence on Return on Equity and this is the same for GDP growth on Return on Equity with a P-value greater than 5\%.In economic magnitude, this result suggests that the interactive effect of default risk administration and macroeconomic variables have an incremental influence on Return on Equity of banks.
Table 3: OLS Result One

\begin{tabular}{|c|c|c|c|c|c|c|}
\hline Source & SS & $d f$ & MS & Number of abs & $=$ & 104 \\
\hline Model & 48.5153559 & 5 & 9.70307119 & Prob $>\mathbb{E}$ & $=$ & 0.0179 \\
\hline Residual & 329.499114 & 98 & 3.36223586 & R-squared & $=$ & 0.1283 \\
\hline Total & 378.01447 & 103 & 3.6700434 & Root MSE & $=$ & 1.8336 \\
\hline
\end{tabular}

\begin{tabular}{r|rrrrrr}
\hline roe & Coef. & Std. Brr. & $\mathrm{t}$ & $\mathrm{p}\rangle|\mathrm{t}|$ & [958 Conf. Interva1] \\
\hline npl & -5.521268 & 5.301652 & -1.04 & 0.300 & -16.04222 & 4.999687 \\
gdp & -4.980579 & 11.27874 & -0.44 & 0.660 & -27.36288 & 17.40172 \\
& & & & & & \\
c.npl\$c.gqpp & 178.4544 & 81.07373 & 2.20 & 0.030 & 17.56621 & 339.3426 \\
& & & & & & \\
log_agget & .3266861 & .5909003 & 0.55 & 0.582 & -.8459362 & 1.499308 \\
crr & 2.420015 & 3.593042 & 0.67 & 0.502 & -4.710259 & 9.55029 \\
cong & -2.934825 & 5.394776 & -0.54 & 0.588 & -13.64058 & 7.770933 \\
\hline
\end{tabular}

Source: Researchers' Computation using eviews 9 (2019) 
Table 4 shows the influence of the interactive effect between capital adequacy ratio and gross national income (GNI) on Return on Asset by presenting the OLS result at a P-value of 0.0 with $\mathrm{R}^{2}$ equaling 0.5584 . This means that including control variables, macroeconomic variables and credit risk management proxies explain $55.84 \%$ of the Return on Asset. From the table, the interaction between capital adequacy ratio and gross national income (GNI) is positively significant on Yield on Asset. The positive coefficient could signal a favorable effect on Return on Asset. However, capital adequacy ratio has an insignificant positive influence on Yield on asset and this is the same for gross national income (GNI) on Yield on Asset with a P-value greater than 5\%.In economic magnitude, this result suggests that the interactive outcome of default risk supervision and macroeconomic variables has an incremental impact on Return on Asset of deposit money banks.

Table 4: OLS Result Two

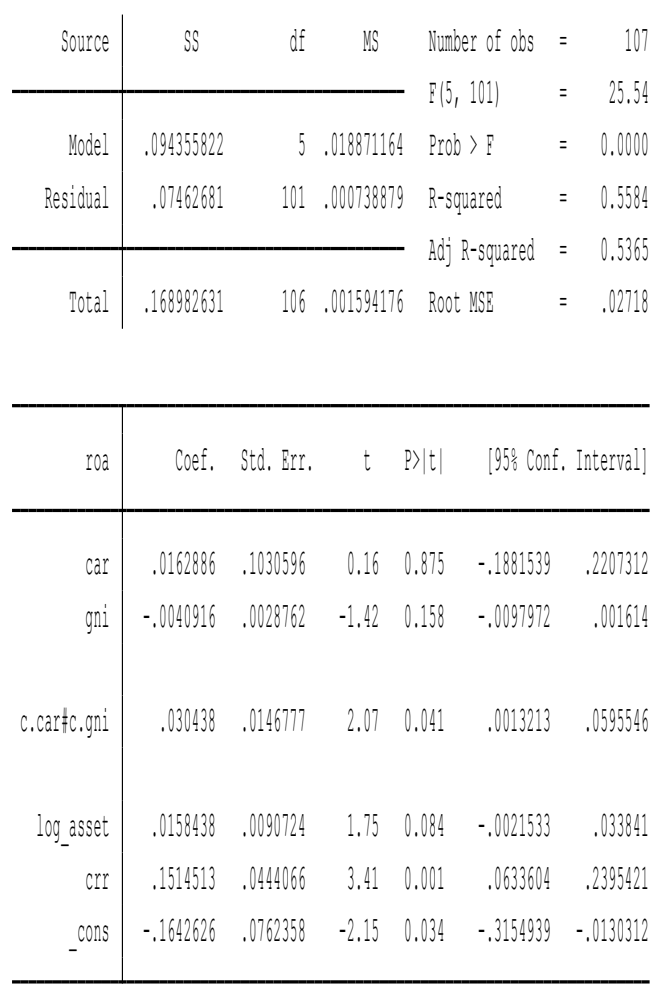

Source: Researchers' Computation using eviews 9 (2019)

Table 5 shows the influence of the interactive effect between advance to lodgment Ratio and Inflationary rate on net interest spread by presenting the OLS outcome at a P-value of 0.0 with $\mathrm{R}^{2}$ equaling 0.9670. This means that including control variables, macroeconomic variables and credit risk management proxies explain $96.70 \%$ of Net Interest Margin. From the table, the interactive effect between Loan to Deposit Ratio and degree of Inflation is inversely insignificant on Net Interest spread. The negative coefficient could signal a detrimental effect on bank profitability as inflation negatively affects the economy which in turn would affect the project for which the credit was taken. Furthermore, deposit proportion had an insignificant effect on bank profitability (Net Income Margin) with a P-value above 5\%. However, inflationary rate has a negatively significant outcome with respect to Net Interest spread with a P-value lower than 5\%.Regarding economic magnitude, this result suggests that the interactive effect of default risk supervision and macroeconomic variables has the ability to decrease the Net Interest Margin of Deposit Money Banks.

Table 5: OLS Result Three
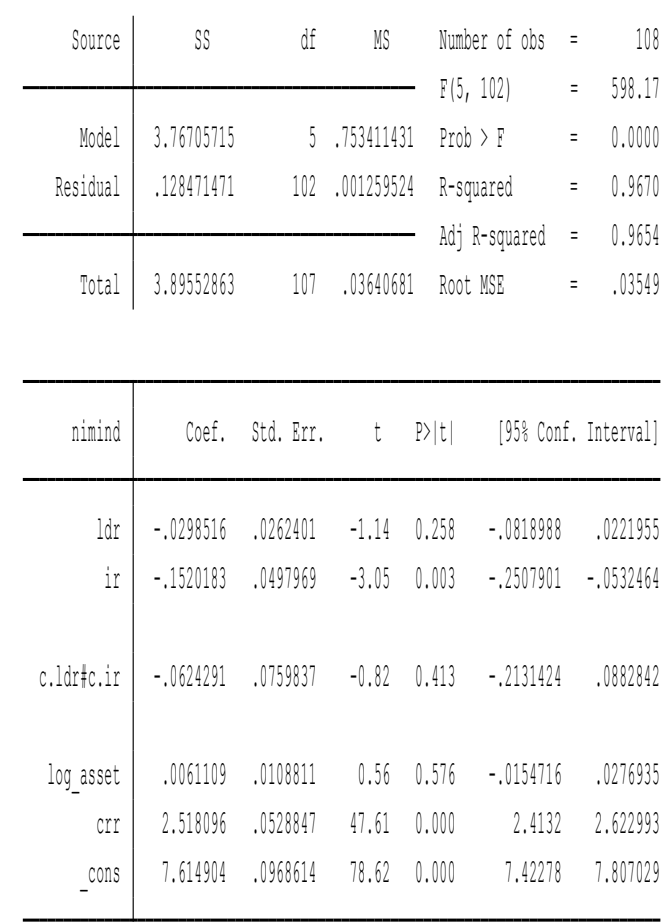

Source: Researchers' Computation using eviews 9 (2019)

\section{Conclusion}

The overriding reason for this analysis was to evaluate the dynamic influence of default risk administration and macro-economic factors on the financial accomplishment of deposit money banks. The findings of the investigation indicate that the ascent in GDP progression rate and the un- 
Performing advance would lead to an increment in bank output as far as performance that may be due to economic development and also [26]; [15]; and [16] to a transition in loan losses in the system of a large interest spread to other customers. The study showed the presence of a positive connection between the capital adequacy proportion and the sum national income on the Return on Asset. Therefore, Depositing Money Banks with a greater proportion of capital sufficiency can all the more likely develop more advances and retain credit misfortunes whenever it occurs and thus document better financial productivity as for the assets. In the case that an increasing inflation rate is caused by the economy, loan-to-deposit ratio will adversely influence the net income spread of the DMBs as the spread of interest rates rises and savers are unwilling to store funds in the financial institutions, and this scenario induces the banks ' strain in sourcing trustworthy lenders at the point when the loaning rate is excessively high. This paper concludes that the interaction between GDP progression rate and Gross National Income (GNI) with un-performing advance and the capital adequacy proportion respectively have the greatest impact on the efficiency output of store cash banks. The effect of the loan-to-deposit ratio and inflation on the net income spread is statistically insignificant.

\subsection{RECOMMENDATIONS}

The following suggestions are derived from the research findings:-

a. In Nigeria, the report advises that DMBs strengthen and maintain strict commitment to their credit risk plans, evaluations, and review. Banks are responsible for ensuring cash are allotted to debtors with a reasonable to impressive credit scores.

b. Banks shall conform to the applicable requirements of the Banks and Other Financial Institutions Act (1999) as amended and the Guiding principle for Prudentials'.

c. Banks should gather all necessary and unbiased information from both internal and external sources, as well as on the impression of the macroeconomic situation on default risk administration, with an objective to access the vast array of default risk in the loan propositions.

d. Banks must be well capitalized to cushion the loan loss from un-performing advances relative to the size of lending portfolio and regulatory requirements.

\section{References:}

[1] Abdelrahim, K. E. Effectiveness of credit risk management of Saudi Banks in the light of global financial crisis: A qualitative study. Asian Transactions on Basic and Applied Sciences, Vol. 3, No. 1, (2013), pp. $12-22$.

[2] Abid, S. F., \& Lodhi, S. Impact of changes in reserve requirement on banks profitability: A case of commercial banks in Pakistan. European Journal of Business and Management, Vol. 7, No. 31, (2015), pp. 1-6.

[3] Adeola, O., \& Ikpesu, F. Macroeconomic determinants of non-performing loans In Nigeria: An empirical analysis. Journal of Developing Areas, Vol. 51, No. 2, (2017), 31-43.

[4] Adeusi, S. O., Akeke, N. I., Adebisi, O. S., $\&$ Oladunjoye, O. Risk management and financial performance of banks in Nigeria. Finance Journal, Vol. 12, No. 4, (2014), pp. $1-12$

[5] Aduda, J. \& Gitonga, J. The relationship between credit risk management and profitability among the commercial banks in Kenya. Journal of Modern Accounting and Auditing, Vol. 7, No. 9, (2011), 9-34

[6] Afriyie, H. O. \& Akotey, J. O. Credit risk management and profitability of selected rural banks in Ghana. Catholic University College of Ghana Journal. Vol. 2, No. 1, (2012), pp. 13-24

[7] Alshatti, A. S. The effect of credit risk management on financial performance of the Jordanian commercial banks. Investment Management and Financial Innovations, Vol. 12, No. 1, (2015), 338345.

[8] Akinselure, O. P. \& Akinola, A. T. Impact of credit risk management on profitability of selected deposit money banks in Nigeria. International Journal of 
Economics, Commerce and Management, Vol. 8, No. 9, (2019), pp. $37-48$

[9] Alobari, C., Naenwi, M., Zukbee, S. O., \& Grend, M. D. Impact of credit management on bank performance in Nigeria. Equatorial Journal of Finance and Management Sciences, Vol. 3, No. 1, (2018), pp. 17 - 23.

[10] Athanasoglou, P. P., Brissimis, S. N., \& Delis, M. D.. Bank-specific, industryspecific and macroeconomic determinants of bank profitability. Journal of international financial Markets, Institutions and Money, Vol. 18, No. 2, (2008), pp. $121-136$

[11] Bhattarai, Y. R. Effect of credit risk on the performance of Nepalese commercial banks. Journal of Management and Finance, Vol. 1, No. 1, (2014), pp. 41-64.

[12] Chidozie, E. \& Ayadi, S. Macroeconomy and banks' profitability in Nigeria. International Multi-disciplinary Journal, Ethiopia, Vol. 11, No. (2), (2017), pp. 121137.

[13] Davis , O. \& Ngozi, O. Credit risk and economic growth in Nigeria. European Journal of Business, Economics and Accountancy. Vol. 12, No. 4, (2019), pp. $35-47$

[14] Ghyasi, A. Effect of macroeconomic factors on credit risk of banks in developed and developing countries: Dynamic panel method. International Journal of Economics and Financial Issues, Vol. 6, No. 4, (2016), 1937-1944.

[15] Isibor, A.A., Felicia, O., Maria, A., Godswill, O., and Chisom, N.. Exchange rate management and sectoral output performance. International Journal of Supply Chain Management, Vol. 7, No. 5, (2018), pp. 129-134

[16] Isibor, A., Ojo, J. A. T., and Ikpefan, O. A.
Does financial deregulation spur economic development in Nigeria? Peer-Reviewed Proceedings of the International Business Information Management Association Conference (31st IBIMA) held on $25-26$ April 2018, Milan, Italy.

[17] Jaroslav , B., Lubos , S., Beata , G., \& Jan, D. The impact of social and economic factors in the credit risk management of sme. Technological and Economic Development of Economy, Vol. 24, No. 3, (2018), pp. 1215-1230.

[18] Kaaya, I., \& Pastory, D. Credit risk and commercial banks performance in Tanzania: A panel data analysis. Research Journal of Finance and Accounting, Vol. 4, No. 16, (2013), pp. 55-62.

[19] Kurawa, J. M., \& Garba, S. An evaluation of the effect of credit risk management (CRM) on the profitability of Nigerian banks. Journal of Modern Accounting and Auditing, Vol. 10, No. 1, (2014), 104-123.

[20]Lehar, A. Measuring systemic risk: A risk management approach. Journal of Banking \& Finance, Vol. 29, No. 10, (2005), pp. 2577-2603.

[21]Liu, X., \& Zhang, C. Corporate governance, social responsibility information disclosure, and enterprise value in China. Journal of Cleaner Production, Vol. 14, No. 2, (2017), pp. 1075-1084.

[22]Mileris, R. The impact of macroeconomic environment on credit risk in commercial banks. Vol. 3, No. 1, (2015), pp. $17-29$

[23] Ndoka, S. \& Islami, M. The impact of credit risk management in the profitability of Albanian commercial banks during the period 2005-2015. European Journal of Sustainable Development, Vol. 5, No. 3, (2016), pp. 44 - 56.

[24] Ogboi, C., \& Unuafe, O. K. Impact of 
credit risk management and capital adequacy on the financial performance of commercial banks in Nigeria. Journal of emerging issues in economics, finance and banking, Vol. 2, No. 3, (2013), pp. 703717.

[25] Olaoye , F., \& Ojuolape, T. C. Credit risk disclosure compliance and bank performance in Nigeria: Case-study of Zenith bank. Archives of Business Research, Vol. 1, No. 1, (2019), pp. 1 - 14

[26] Patrick, O. N., Ikenna, J. E.and Ekemezie, L. I. The impact of credit risk management on deposit money banks performance in Nigeria. Nigerian Journal of Management Sciences, Vol. 6, No. 1, (2017), pp. $120-$ 134

[27] Poudel, R. P. S. The impact of credit risk management on financial performance of commercial banks in Nepal. International Journal of arts and commerce, Vol. 1, No. 5, (2012), pp. 9-15.

[28] Radivojevic, N., \& Jovovic, J. Examining of Determinants of NonPerforming Loans. Prague Economic Papers, Vol. 26, No. 3, (2017), pp. 300-316.

[29] Saba, I., Kouser, R., \& Azeem, M. Determinants of Non Performing Loans: Case of US Banking Sector. The Romanian Economic Journal, Vol. 44, No. 6, (2012), pp. 125-136.

[30] Skarica, B. Determinants of nonperforming loans in Central and Eastern European countries. Financial Theory and Practice, Vol. 38, No. 1, (2014), 37-59.

[31] Udom, I. S., Agboegbulem, N. T. I., Atoi, N. V, Adeleke, A. O., Abraham, O., Onumonu, O. G., \& Abubakar, M. Modelling banks 'interest margins in Nigeria. CBN Journal of Applied Statistics, Vol. 7, No. 1, (2016), pp. 1-26.

[32] Uwalomwa , U., Uwuigbe, , O. R., \&
Oyewo, B. Credit Management and Bank Performance of Listed Banks in Nigeria. Journal of Economics and Sustainable Development, Vol. 6, No. 5, (2015), pp. 1 $-12$

[33] Valeria Bondarenko, Simona FilipovaPetrakieva, Ina Taralova, Desislav Andreev, Forecasting time series for power consumption data in different buildings using the fractional Brownian motion, International Journal of Circuits, Systems and Signal Processing, Vol. 12, (2018), pp. 646-652

[34]Xiaohua Duan, Systematic Risk Measurement Based on CoVaR Model, International Journal of Circuits, Systems and Signal Processing, , Vol. 13, No. 4, (2019), pp. 243-250

[35]Zou, Y., \& Li, F. The impact of credit risk management on profitability of commercial banks: A study of Europe. International Journal of Financial Studies, Vol. 10, No. 4, (2014), pp. 14 - 26

\section{Authors' Contribution}

Isibor Areghan was responsible for proof-reading and editing the work.

Omankhanlen Alexander was responsible for supervising the study and references.

Chima Mathias carried out the introduction and literature review.

Komolafe Titilope gathered the data, defined the methodology.

Okereke Yvonne analyzed the data and did recommendations and conclusion.

\section{Creative Commons Attribution License 4.0 (Attribution 4.0 International, CC BY 4.0)}

This article is published under the terms of the Creative Commons Attribution License 4.0

https://creativecommons.org/licenses/by/4.0/deed.en US 